\title{
Cell therapy in the treatment of bipolar mania in an animal model: a proof of concept study
}

\author{
Terapia celular no tratamento do transtorno bipolar: estudo piloto em um \\ modelo animal de mania
}

Bruna M. Ascoli,,$^{1,2}$ Rafael Colombo, ${ }^{1,3}$ Luiza P. Géa, ${ }^{1,4}$ Paula B. Terraciano, ${ }^{5}$ Sabrina B. Pizzato, ${ }^{5}$ Fernanda S. de Oliveira, ${ }^{5}$ Elizabeth Cirne-Lima, ${ }^{5,6,7}$ Flávio Kapczinski, ${ }^{1,2,8}$ Adriane R. Rosa 1,2,4,9

\begin{abstract}
Introduction: The rationale of mesenchymal stem cells (MSCs) as a novel therapeutic approach in certain neurodegenerative diseases is based on their ability to promote neurogenesis. Hippocampal atrophy has been related to bipolar disorder (BD) in preclinical, imaging and postmortem studies. Therefore, the development of new strategies to stimulate the neurogenesis process in BD is crucial.

Objectives: To investigate the behavioral and neurochemical changes induced by transplantation of MSCs in a model of manialike behavior induced by lisdexamfetamine dimesylate (LDX).

Methods: Wistar rats $(n=65)$ received one oral daily dose of LDX $(10 \mathrm{mg} / \mathrm{kg})$ or saline for 14 days. On the 8 th day of treatment, the animals additionally received intrahippocampal saline or MSC (1 $\mu \mathrm{L}$ containing 25,000 cells) or lithium $(47.5 \mathrm{mg} / \mathrm{kg}$ ) as an internal experimental control. Two hours after the last administration, behavioral and neurochemical analyses were performed.

Results: LDX-treated rats had increased locomotor activity compared to saline-saline rats $(p=0.004)$, and lithium reversed LDX-related hyperactive behavior $(p<0.001)$. In contrast, the administration of MSCs did not change hyperlocomotion, indicating no effects of this treatment on LDX-treated rats $(p=0.979)$. We did not find differences between groups in BDNF levels $(p>0.05)$ in the hippocampus of rats.

Conclusion: Even though these results suggest that a single intrahippocampal injection of MSCs was not helpful to treat hyperactivity induced by LDX and neither influenced BDNF secretion, we cannot rule out the possible therapeutic effects of MSCs. Further research is required to determine direct effects of LDX on brain structures as well as in other pathophysiological targets related to BD.
\end{abstract}

Keywords: Mesenchymal stem cells, cellular therapy, bipolar disorder, mania, neurogenesis, hippocampus.

\section{Resumo}

Introdução: Células-tronco mesenquimais (CTMs) têm emergido como um promissor tratamento em diversas doenças neurodegenerativas devido a sua plasticidade e capacidade de regenerar tecidos. Estudos pré-clínicos, clínicos e de neuroimagem têm demonstrado a presença de atrofia hipocampal no transtorno bipolar (TB). Portanto, o desenvolvimento de tratamentos capazes de regenerar tecido lesado e estimular a neurogênese poderia ser útil.

Objetivos: Investigar mudanças comportamentais e neuroquímicas induzidas pelo transplante de CTMs no hipocampo de ratos em um modelo animal de mania induzido por dimesilato de lisdexanfetamina (LDX).

Métodos: Ratos Wistar $(\mathrm{n}=65)$ receberam LDX $(10 \mathrm{mg} / \mathrm{kg})$ ou solução salina por via oral durante 14 dias. No oitavo dia, os animais foram transplantados com injeção de CTMs ou solução salina ( $1 \mu \mathrm{L}$ contendo 25.000 células) ou lítio $(47,5 \mathrm{mg} / \mathrm{kg})$ como controle interno do experimento. Duas horas após a última dose, foram realizadas análises comportamentais e neuroquímicas.

Resultados: Animais que receberam LDX tiveram um aumento da atividade locomotora comparados ao grupo que recebeu solução salina $(p=0,004)$; já o lítio reverteu a hiperatividade locomotora desses animais $(p<0,001)$. Os animais que receberam CTMs não apresentaram alterações no comportamento, indicando ausência de efeitos sobre hiperatividade locomotora. Os níveis de BDNF hipocampais não diferiram entre os grupos $(p>0.05)$.

Conclusão: Não foi possível demonstrar efeitos neuroprotetores das CTMs, administradas em dose única, em um modelo animal de mania induzido por LDX. No entanto, não se pode descartar os possíveis efeitos terapêuticos das CTMs. Mais estudos são necessários para determinar os efeitos das CTMs em estruturas cerebrais e outros alvos fisiopatológicos relacionados ao TB. Descritores: Células mesenquimais, terapia celular, transtorno bipolar, mania, neurogênese, hipocampo.

\footnotetext{
${ }^{1}$ Laboratório de Psiquiatria Molecular, Hospital de Clínicas de Porto Alegre (HCPA), Porto Alegre, RS, Brazil. 2 Programa de Pós-Graduação em Psiquiatria e Ciências do Comportamento, Universidade Federal do Rio Grande do Sul (UFRGS), Porto Alegre, RS, Brazil. ${ }^{3}$ Laboratório de Farmacologia e Fisiologia, Universidade de Caxias do Sul (UCS), Caxias do Sul, RS, Brazil. ${ }^{4}$ Programa de Pós-Graduação em Farmacologia e Terapêutica, UFRGS, Porto Alegre, RS, Brazil. ${ }^{5}$ Laboratório de Embriologia e Diferenciação Celular, Centro de Pesquisa Experimental, HCPA, Porto Alegre, RS, Brazil. ${ }^{6}$ Departamento de Patologia Clínica Veterinária, Faculdade de Veterinária, UFRGS, Porto Alegre, RS, Brazil. ${ }^{7}$ Programa de Pós-Graduação em Ginecologia e Obstetrícia, UFRGS, Porto Alegre, RS, Brazil. ${ }^{8}$ Departamento de Psiquiatria, UFRGS, Porto Alegre, RS, Brazil. ${ }^{9}$ Departamento de Farmacologia, UFRGS, Porto Alegre, RS, Brazil.

Submitted Oct 18 2016, accepted for publication Feb 142017.

Suggested citation: Ascoli BM, Colombo R, Géa LP, Terraciano PB, Pizzato SB, de Oliveira FS, et al. Cell therapy in the treatment of bipolar mania in an animal model: a proof of concept study. Trends Psychiatry Psychother. 2017;39(3):196-201. Epub 15 May 2017. http://dx.doi.org/10.1590/2237-6089-2016-0074
} 


\section{Introduction}

Bipolar disorder (BD) is a chronic, recurrent and disabling mental illness. Although current treatments used for BD can relieve mood symptoms, they do not cure. Furthermore, relapse is always a risk. ${ }^{1}$ Therefore, it is essential to develop more effective therapeutic approaches to treat BD.

Mesenchymal stem cells (MSCs) are self-renewing multipotent progenitor cells that have the capacity of differentiating into all lineages of mesodermal origin and non-skeletal cell types, including neurons. ${ }^{2-4}$ They exhibit the ability to migrate to injured sites, and this mechanism involves the expression of specific receptors to facilitate reaching the target site, adhering to and infiltrating the damaged tissue. ${ }^{2-4}$ Moreover, the therapeutic effectiveness of MSCs depends on their ability to secrete trophic factors that can stimulate the surrounding microenvironment and promote the regeneration of endogenous cells. In particular, MSCs produce brain-derived neurotrophic factor (BDNF), an important protein that stimulates neuroplasticity and neurogenesis in the hippocampus. ${ }^{2-4}$

Neurogenesis, the process by which new neurons are generated from neural stem cells, is continuous in the adult brain and essential for the maintenance of plasticity and cognitive function..$^{3-6}$ An increasing body of evidence links impairment in hippocampal neurogenesis to BD. ${ }^{2}$ For instance, a sample of individuals with euthymic BD-I disorder revealed significantly smaller left hippocampal volume in BD-I patients compared with healthy controls, with shape analysis revealing specific reductions in the anterior head and medial border of the left hippocampus. ${ }^{7}$ Another neuroimaging study examined the effect of the BDNF val66met genotype on hippocampal volumes in patients with mood disorders, showing a strong association between the BDNF val66met polymorphism and reduced hippocampal volumes in BD-I patients. ${ }^{8}$ Serum BDNF levels are also decreased in manic and depressed bipolar patients in comparison with euthymic and healthy controls. ${ }^{9}$ Furthermore, lithium, a mood-stabilizer used for the treatment of $B D$, exerts trophic actions on hippocampus, as an increase in total hippocampal volume has been found in patients exposed to lithium compared to those who did not receive this therapy. ${ }^{10}$

Considering that BD is associated with hippocampal atrophy, the development of novel therapeutic strategies to stimulate neurogenesis is crucial. The rationale of MSCs as an alternative treatment of BD is based on their differentiation potential and migratory properties that enable tissue replacement. The aim of the present study was to investigate the behavioral and neurochemical changes induced by stereotaxic transplantation of
MSCs in a model of mania-like behavior induced by lisdexamfetamine dimesylate (LDX).

\section{Materials and methods}

\section{Ethical approval}

This study was approved by the institutional ethics committee and performed in accordance with Brazilian and international guidelines for animal experimentation. ${ }^{11}$

\section{Isolation and culture of mouse adipose-derived MSC}

Epidydimal fat from male $\mathrm{C} 57 \mathrm{BL} / 6$ mice was aseptically removed and enzymatically digested with $1 \mathrm{mg} / \mathrm{mL}$ of collagenase type I (Sigma, St. Louis, MO, United States). Obtained cell suspensions were maintained in Dulbecco's modified eagle medium (DMEM) with $200 \mathrm{~mL} / \mathrm{L}$ fetal bovine serum (FBS) (Gibco, Carlsbad, CA, United States) and 100 units $/ \mathrm{mL}$ penicillin and $100 \mathrm{mg} / \mathrm{mL}$ streptomycin (Gibco). They were incubated at $37{ }^{\circ} \mathrm{C}$ in a humidified atmosphere containing $50 \mathrm{~mL} / \mathrm{L} \quad \mathrm{CO}_{2}$. Adherent cells achieving $80 \%$ confluence were split using $2.5 \mathrm{~mL} / \mathrm{L}$ trypsinethylenediaminetetraacetic acid solution (Gibco) and maintained in DMEM supplemented with $200 \mathrm{~mL} / \mathrm{L}$ FBS and $1 \%$ of an antibiotic solution. In vivo administered MSCs were used between passages 3-6.

In parallel, MSC characterization experiments were performed by in vitro differentiation and immunophenotyping analysis according to Schneider et al. ${ }^{12}$

\section{Animal model of mania-like behavior and cell transplantation}

We used a model of mania-like behavior induced by LDX as previously described in Macêdo et al. ${ }^{13}$ The experiments were performed in adult male Wistar rats (aged 60 days) obtained from the Animal House of Universidade Federal do Rio Grande do Sul. Animals were divided into six groups of 9-12 each $(n=65)$. Each group of animals received one oral daily dose of LDX $(10 \mathrm{mg} / \mathrm{kg}$ ) or saline for 14 days. On the 8th day of treatment, the animals additionally received saline ( $1 \mu \mathrm{L}$, intrahippocampal injection) or MSC ( $1 \mu \mathrm{L}$ containing 25,000 cells, intrahippocampal injection). Additionally, a group of animals received lithium (47.5 $\mathrm{mg} / \mathrm{kg}$, intraperitoneal injection, twice a day) as an internal (positive) experimental control. All animals were maintained on a 12-hour light-dark cycle and received water and food ad libitum.

\section{Surgery}

Animals were implanted with bilateral $14-\mathrm{mm}$ or 9.0$\mathrm{mm}, 23$-gauge guide cannulae aimed $1.0 \mathrm{~mm}$ above the 
CA1 area of the dorsal hippocampus, under anesthesia with ketamine $(75 \mathrm{mg} / \mathrm{kg}$ ) and xylazine $(25 \mathrm{mg} / \mathrm{kg})$. Coordinates (were obtained from the atlas of Paxinos \& Watson ${ }^{14}$ (anteroposterior, $-4.3 \mathrm{~mm}$ from bregma; mediolateral, $\pm 3.0 \mathrm{~mm}$ from bregma; ventral, $-2.0 \mathrm{~mm}$ from skull surface). Animals were allowed to recover for at least five days after surgery.

\section{Open-field test}

Spontaneous locomotor activity was evaluated in an open field apparatus which consisted of a circular arena (78 cm in diameter and $36 \mathrm{~cm}$-high walls) with an open top and a dark floor divided into 25 spaces. Animals were gently placed in the arena for $15 \mathrm{~min}$, and each test was recorded with a digital camera. After each individual animal test, the apparatus was cleaned with a $70 \%$ alcohol solution. To evaluate locomotion, the number of lines crossed, distance travelled $(m)$, average speed $(\mathrm{m} / \mathrm{s})$ and the number of rearings were analyzed. After this task, rats were sacrificed by decapitation, and brain tissue was prepared and used for determination of BDNF levels.

\section{Measurement of hippocampal BDNF levels}

The levels of BDNF were determined in each sample by enzyme immunoassays (ELISA; Millipore, USA) according to the manufacturer's instructions.

\section{Results}

To explore the effects of MSC on mania-like animal model locomotor activity was assessed two hours after the last LDX injection (Figure 1). In this study, two-way ANOVA of number of crossings showed a significant interaction between LDX protocol and treatment groups $(F 2=3.913, p=0.026)$ with a significant main effect of LDX protocol $(\mathrm{F} 1=27.494, \mathrm{p}<0.001)$ and treatment groups $(F 2=33.623, p<0.001)$. As expected, LDX-treated rats had increased locomotor activity compared to saline-saline rats $(p=0.004)$, and lithium reversed LDXrelated hyperactive behavior $(p<0.001)$. In contrast, the administration of MSCs did not change hyperlocomotion, indicating no effects of this treatment on LDX-treated rats $(p=0.979)$.
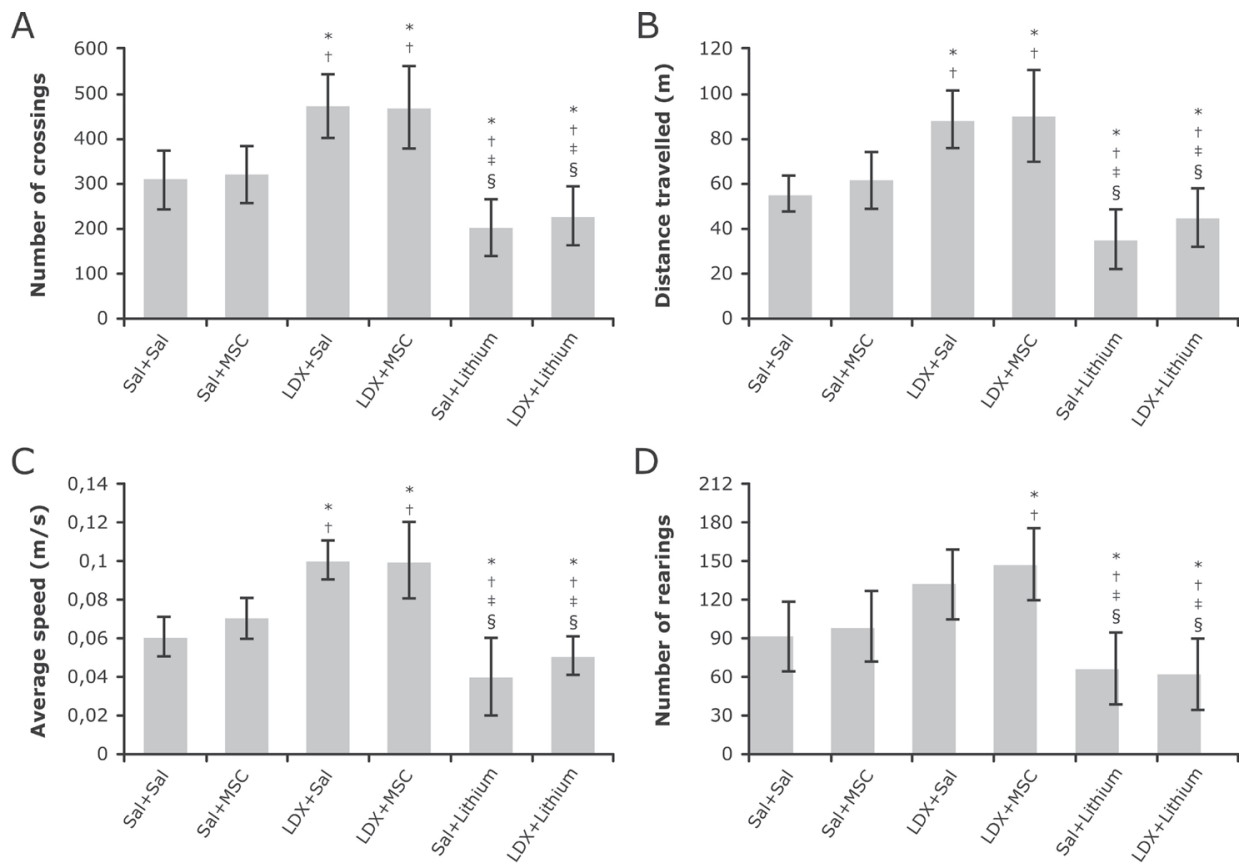

Figure 1 - Effect of MSC injection on spontaneous locomotor activity of LDX-treated rats in the open field. Exploratory activities such as frequency of crossings (A), distance travelled (B) and average speed (C) were increased in LDX+Sal and LDX+MSC groups, compared

to Sal+Sal and Sal+MSC, while lithium reduced these parameters. Regarding the frequency of rearings (D), the LDX+MSC group

exhibited a more exploratory behavior than Sal+Sal and Sal+MSC, and treatment with lithium reduced this frequency, as expected.

All data were analyzed by one-way ANOVA followed by Tukey's post hoc. Results expressed as mean \pm standard deviation. $* p<0.05$ compared to Sal+Sal; ${ }^{\dagger} \mathrm{p}<0.05$ compared to Sal+MSC; ${ }^{\ddagger} \mathrm{p}<0.001$ compared to LDX+Sal; and ${ }^{\S} \mathrm{p}<0.001$ compared to LDX+MSC. LDX $=$ lisdexamfetamine; $\mathrm{MSC}=$ mesenchymal stem cell; Sal = saline. 
Regarding rearing behavior, there was also a significant interaction between both factors $(F=12.099, p<0.001)$, with significant main effects of treatment groups $(F=21.972, p<0.001)$ and a trend effect of LDX protocol $(F=3.608, p=0.063)$. Post hoc analysis showed increased rearing behavior in LDX-treated rats compared to salinesaline rats $(p<0.001)$; however, these effects were not reversed by MSCs $(p=0.947)$ or lithium $(p=0.207)$.

With regards to distance, significant main effects of LDX protocol $(F 1=33.390, p<0.001)$ and treatment groups $(F 2=33.558, p<0.001)$ were observed. Post hoc analysis showed increased distance of LDX-treated rats compared to controls $(p<0.001)$, and lithium reversed such effects. The administration of MSCs did not change this behavior $(p=0.944)$.

Furthermore, we found differences in hippocampal BDNF levels between the groups $(F=2.661, p=0.046)$. However, there were no intergroup differences in the post hoc analysis. A non-significant trend for LDX+lithium was observed when this group was compared to Sal+Sal $(p=0.094)$, while no differences were found between LDX+lithium and LDX+Sal $(p=0.864)$.

\section{Discussion}

This is the first study to treat LDX-induced mania-like behavior with intrahippocampal transplantation of MSCs.
We hypothesized that MSCs would improve behavioral function, perhaps emerging as a useful strategy to treat psychiatric disorders. However, our results suggest that a single intrahippocampal injection of MSCs, at a particular time-point of a behavioral study, did not reverse a specific mania-like behavior or influence BDNF levels.

Some preclinical studies have revealed effects of MSCs in various CNS diseases, showing positive results (see Table 1). However, most of these studies focused on neurodegenerative diseases, which are characterized by injury to a particular area of the brain. In Parkinson's disease, for instance, the loss of dopaminergic neurons occurs mainly in the substantia nigra. In this case, MSCs may migrate to this region and promote tissue regeneration through their immunomodulatory properties and secretion of trophic factors. In contrast, BD is characterized by dysfunctions in distinct areas of the brain, particularly in the prefrontal-striatal-pallidal-thalamic-limbic brain networks. ${ }^{20}$ Furthermore, the animal model of manialike behavior induced by LDX causes redox alterations in specific brain areas (hippocampus, prefrontal cortex and striatum). Therefore, it is possible to speculate that the absence of MSC effects in the present study is due to the characteristics of bipolar illness. In particular, the damage in $\mathrm{BD}$ seems to extend to distinct areas of the brain, thereby diluting the regeneration potential of MSCs.

Furthermore, the route, number of cell doses, time and frequency of MSC administration is critical. In our study,

Table 1 - Effects of MSCs in various CNS diseases

\begin{tabular}{|c|c|c|c|c|c|}
\hline $\begin{array}{l}\text { CNS disease } \\
\text { (reference) }\end{array}$ & $\begin{array}{l}\text { Experimental } \\
\text { model }\end{array}$ & MSC source & Dose & Site of injection & Characteristic \\
\hline Parkinson $^{15}$ & $\begin{array}{l}\text { 6-OHDA-treated } \\
\text { Wistar rats }\end{array}$ & $\begin{array}{l}\text { hMSCs } \\
\text { rMSCs }\end{array}$ & $1 \times 10^{5}$ cells & Intrastriatal & $\uparrow$ Dopaminergic cells \\
\hline Parkinson ${ }^{16}$ & $\begin{array}{l}\text { LPS challenged } \\
\text { Sprague-Dawley rats } \\
\text { and MPTP-treated } \\
\text { C57BL/ } 6 \text { mice }\end{array}$ & hMSCs & $\begin{array}{l}1 \times 10^{6} \text { cells } \\
1 \times 10^{5} \text { cells }\end{array}$ & Intravenous & $\begin{array}{l}\downarrow \text { TH neuronal loss } \\
\downarrow \text { Activation of microglia and } \\
\text { inflammatory markers }\end{array}$ \\
\hline Depression $^{6}$ & $\begin{array}{l}\text { Flinders sensitive line } \\
\text { rats }\end{array}$ & rMSCs & $1 \times 10^{5}$ cells & Intracerebroventricular & $\begin{array}{l}\uparrow \text { Neural markers } \\
\text { Hippocampal neurogenesis } \\
\text { Behavior improvement }\end{array}$ \\
\hline $\begin{array}{l}\text { Depression and } \\
\text { anxiety }{ }^{3}\end{array}$ & Lewis rats & Lewis rMSCs & $3 \times 10^{3}$ cells & Intrahippocampal & $\begin{array}{l}\uparrow \text { Neurogenesis } \\
\text { No alteration in behavioral functions }\end{array}$ \\
\hline $\begin{array}{l}\text { Spinal cord } \\
\text { injury }\end{array}$ & $\begin{array}{l}\text { Spinal cord injured } \\
\text { Sprague-Dawley rats }\end{array}$ & $\begin{array}{l}\text { Bone marrow } \\
\text { of Sprague- } \\
\text { Dawley rats }\end{array}$ & $1 \times 10^{6}$ cells & Intravenous & $\begin{array}{l}\uparrow \text { Locomotor function } \\
\text { Remyelination of axons in the } \\
\text { perilesional region } \\
\text { Microvessel formation }\end{array}$ \\
\hline $\begin{array}{l}\text { Traumatic brain } \\
\text { injury }\end{array}$ & $\begin{array}{l}\text { Traumatic brain } \\
\text { injured Wistar rats }\end{array}$ & hMSCs & $1 \times 10^{6}$ cells & Intravenous & $\begin{array}{l}\uparrow \text { Sucrose preference } \\
\uparrow \text { Working memory }\end{array}$ \\
\hline Parkinson ${ }^{19}$ & $\begin{array}{l}\text { 6-OHDA-treated } \\
\text { Sprague-Dawley rats }\end{array}$ & $\begin{array}{l}\text { MSCs of bone } \\
\text { marrow of } \\
\text { C57BL/6-Tg }\end{array}$ & $\begin{array}{l}1 \times 10^{6} \text { cells } \\
3 \times 10^{5} \text { cells }\end{array}$ & Intranasal & $\begin{array}{l}\uparrow \text { TH activity and BDNF } \\
\downarrow \text { IL-2, IL-6, TNF-a, IFN- } y \text { and GM- } \\
\text { CSF }\end{array}$ \\
\hline
\end{tabular}

CNS = central nervous system; MSC = mesenchymal stem cell; 6-OHDA = 6-hydroxydopamine; hMSCs = human mesenchymal stem cells; rMSCs = rat mesenchymal stem cells; LPS = lipopolysaccharide; MPTP = 1-methyl-4-phenyl-1,2,3,6-tetrahydropyridine; TH = tyrosine hydroxylase; BDNF = brain-derived neurotrophic factor; IL = interleukin; TNF- $\mathrm{a}=$ tumor necrosis factor $\mathrm{a}$; IFN- $\mathrm{y}=$ interferon $\mathrm{Y}$; GM-CSF = granulocyte-macrophage colony-stimulating factor. 
we injected one dose of MSC into the hippocampus on the 8th experimental day. Despite the scarce literature, it has been suggested that the gene expression of factors involved in hippocampal proliferation would increase over a period of seven days. However, Coquery et al. ${ }^{3}$ suggested that changes in the secretion of these factors as well as changes in behavioral outcomes take longer than seven days to occur. Alterations in neurogenesis may occur after two weeks of left intra-cerebroventricular injection of $\mathrm{MSCs},{ }^{6}$ and 50 days after intra-hippocampal injection of MSCs. ${ }^{3}$ All these data would serve as a theoretical basis for the negative findings of our study, leading to the rationale that the seven-day period is not sufficient to promote significant changes in hippocampal structural plasticity and behavioral outcomes.

Although the local injection of MSCs is the most accepted method, it could cause an increase in pressure and bleed on the microstructures that receive these cells. This fact, in turn, may trigger a potentiation of local inflammatory signals and a reaction against the cell graft. ${ }^{21}$ If this is the case, BDNF secretion may have been affected by this acute inflammation or even by the cell death transplanted into the site. In this context, some authors have suggested the intracerebrospinal or intracerebroventricular routes as alternative delivery methods. Although the administration of MSC injection into the cerebrospinal fluid could solve this issue, the amount of cells that reach the target and the inefficient migration of MSCs to the injury may also limit their therapeutic effects. ${ }^{22}$ Methodological differences regarding the time and frequency of cell administration and the amount of cells transplanted may have contributed to the discrepancies between results. Finally, in addition to previous observations, the histological validation that MSCs are thriving in vivo after their hippocampal administration is critical to understand the role of MScS on hippocampal neurogenesis as well as the effects of MSCs on behavior. This limitation may be directly involved with the results observed in the behavior of animals and should be analyzed in future studies.

Psychostimulant-induced models of mania have been used as a preclinical tool (with adequate face, construct and predictive validity) for the assessment of novel therapeutic strategies in the treatment of BD. ${ }^{23}$ The animal model of mania induced by LDX, for instance, showed oxidative stress abnormalities and hyperlocomotion in rats, and both alterations were reversed by lithium. ${ }^{13}$ However, it is plausible to consider that mania-like behavior induced by LDX does not promote some biological changes found in $\mathrm{BD}$, in particular, inflammatory changes and BDNF alterations, which are also potential targets of MSCs. Also, the lack of assessment of hippocampal volume in the LDX model should be considered when interpreting the present results. Future studies should evaluate hippocampal atrophy in the LDX model of mania-like behavior through the use of 5-bromo-2'-deoxyuridine and dendritic branching by a simple Sholl analysis to validate the presence of decreased proliferation in hippocampal tissue or atrophy in this animal model. Finally, due to the complexity of BD, other behavioral measures such as goal-directed behavior, circadian patterns and feeding should have been considered. It is important to point out that all the outcomes mentioned above are crucial for the elaboration of a clear idea about the role of LDX in hippocampal structures and behavioral changes in this mania-like model.

Despite the limitations discussed above, this is the first study to assess cellular therapy for the treatment of $\mathrm{BD}$. It is important to note that, even though there was no reversal of hyperlocomotion or BDNF secretion, we cannot rule out the possible therapeutic effects of MSCs. Future experiments are needed to establish validity parameters for this animal model and determine direct LDX effects in brain structures as well as in other pathophysiological targets related to BD (e.g., inflammatory markers and neurotrophic factors).

\section{Acknowledgments}

Bruna M. Ascoli and Luiza Gea are scholarship recipients from Coordenação de Aperfeiçoamento de Pessoal de Nível Superior (CAPES). Adriane R. Rosa and Flávio Kapczinski receive research support from Conselho Nacional de Desenvolvimento Científico e Tecnológico (CNPq; PQ 2016).

\section{Disclosure}

Flávio Kapczinski has received grant/research support from Astra-Zeneca, Eli Lilly, Janssen-Cilag, Servier, CNPq, Coordenação de Aperfeiçoamento de Pessoal de Nível Superior (CAPES), NARSAD, and Stanley Medical Research Institute; has been a member of the board of speakers for Astra-Zeneca, Eli Lilly, Janssen and Servier; and has served as a consultant for Servier. No other conflicts of interest declared concerning the publication of this article.

\section{References}

1. Post RM, Fleming J, Kapczinski F. Neurobiological correlates of illness progression in the recurrent affective disorders. J Psychiatr Res. 2012;46:561-73. 
2. Kim HW, Rapoport SI, Rao JS. Altered expression of apoptotic factors and synaptic markers in postmortem brain from bipolar disorder patients. Neurobiol Dis. 2010;37:596-603.

3. Coquery N, Blesch N, Stroh A, Fernández-Klettf F, Klein J, Winter C, Priller J. Intrahippocampal transplantation of mesenchymal stromal cells promotes neuroplasticity. Cytotherapy. 2012;14:1041-53.

4. Colpo GD, Ascoli BM, Wollenhaupt-Aguiar B, Pfaffenseller B, Silva EG, Cirne-Lima EO, et al. Mesenchymal stem cells for the treatment of neurodegenerative and psychiatric disorders. An Acad Bras Cienc. 2015;87:1435-49.

5. Kim N, Cho S. New Strategies for overcoming limitations of mesenchymal stem cell-based immune modulation. Int J Stem Cells. 2015;8:54-68.

6. Tfilin M, Sudai E, Merenlender A, Gispan I, Yadid G, Turgeman G. Mesenchymal stem cells increase hippocampal neurogenesis and counteract depressive-like behavior. Mol Psychiatry. 2010;15:1164-75.

7. Quigley SJ, Scanlon C, Kilmartin L, Emsell L, Langan C, Hallahan $B$, et al. Volume and shape analysis of subcortical brain structures and ventricles in euthymic bipolar I disorder. Psychiatry Res. 2015;233:324-30.

8. Harrisberger $F$, Smieskova $R$, Schmidt A, Lenz $C$, Walter A, Wittfeld $\mathrm{K}$, et al. BDNF Val66Met polymorphism and hippocampal volume in neuropsychiatric disorders: A systematic review and meta-analysis. Neurosci Biobehav Rev. 2015;55:107-18.

9. Cunha AB, Frey BN, Andreazza AC, Goi JD, Rosa AR, Gonçalves $C A$, et al. Serum brain-derived neurotrophic factor is decreased in bipolar disorder during depressive and manic episodes. Neurosci Lett. 2006;398:215-9.

10. Hajek T, Bauer M, Simhandl C, Rybakowski J, O’Donovan C, Pfennig A, et al. Neuroprotective effect of lithium on hippocampal volumes in bipolar disorder independent of long-term treatment response. Psychol Med. 2014;44:507-17.

11. National Research Council (US) Committee for the Update of the Guide for the Care and Use of Laboratory Animals. Guide for the care and use of laboratory animals. 8th ed. Washington: National Academies Press; 2011.

12. Schneider N, Gonçales FC, Pinto FO, Lopez PLC, Araújo AB, Pfaffenseller $B$, et al. Dexamethasone and azathioprine promote cytoskeletal changes and affect mesenchymal stem cell migratory behavior. Plos One. 2015;10;1-20.

13. Macêdo DS, de Lucena DF, Queiroz AI, Cordeiro RC, Araújo MM, Sousa FC, et al. Effects of lithium on oxidative stress and behavioral alterations induced by lisdexamfetamine dimesylate: relevance as an animal model of mania. Prog Neuropsychopharmacol Biol Psychiatry. 2013;43:230-7.
14. Paxinos G, Watson C. The rat brain in stereotaxic coordinates: hard cover edition. 6th ed. Cambridge: Academic Press; 2006.

15. Dezawa M, Kanno $H$, Hoshino M, Cho H, Matsumoto N, Itokazu $Y$, et al. Specific induction of neuronal cells from bone marrow stromal cells and application for autologous transplantation. J Clin Investig. 2004;113:1701-10.

16. Kim YJ, Park HJ, Lee G, Bang OY, Ahn YH, Joe E, et al. Neuroprotective effects of human mesenchymal stem cells on dopaminergic neurons through anti-inflammatory action. Glia. 2009;57:13-23.

17. Morita T, Sasaki M, Kataoka-Sasaki Y, Nakazaki M, Nagahama $\mathrm{H}$, Oka $\mathrm{S}$, et al. Intravenous infusion of mesenchymal stem cells promotes functional recovery in a model of chronic spinal cord injury. Neuroscience. 2016;335:221-31.

18. Darkazalli A, Ismail AA, Abad N, Grant SC, Levenson CW. Use of human mesenchymal stem cell treatment to prevent anhedonia in a rat model of traumatic brain injury. Restor Neurol Neurosci. 2016;34:433-41.

19. Danielyan L, Beer-Hammer S, Stolzing A, Schäfer R, Siege $\mathrm{G}$, Fabian $\mathrm{C}$, et al. Intranasal delivery of bone marrowderived tem cells, macrophages, and microglia to the brain in mouse models of Alzheimer's and Parkinson's disease. Cell Transplant. 2014;23:S123-39.

20. Strakowski SM, Adler CM, Almeida J, Altshuler LL, Blumberg HP, Chang KD, et al. The functional neuroanatomy of bipolar disorder: a consensus model. Bipolar Disord. 2012;14:313-25.

21. Janowski M, Engels C, Gorelik M, Lyczek A, Bernard S, Bulte JW, et al. Survival of neural progenitors allografted into the CNS of immunocompetent recipients is highly dependent on transplantation site. Cell Transplant. 2014;23:253-62.

22. Habisch $\mathrm{HJ}$, Janowski M, Binder D, Kuzma-Kozakiewicz M, Widmann $A$, Habich $A$, et al. Intrathecal application of neuroectodermally converted stem cells into a mouse model of ALS: limited intraparenchymal migration and survival narrows therapeutic effects. J Neural Transm (Vienna). 2007;114:1395-406.

23. SharmaAN, FriesGR, GalvezJF, ValvassoriSS, Soares]C, CarvalhoAF, etal. Modeling mania in preclinical settings: Acomprehensivereview. Prog Neuropsychopharmacol Biol Psychiatry. 2016;66:22-34.

\section{Correspondence:}

Adriane Ribeiro Rosa

Laboratório de Psiquiatria Molecular

Hospital de Clínicas de Porto Alegre (HCPA)

Av. Ramiro Barcelos, 2350, CEP 90035-903

Porto Alegre, RS - Brazil

E-mail: adrianerrosa@gmail.com 